\title{
Penal Policies Pursued Toward Juveniles in Albania
}

\section{Antoneta Gjolena}

European University of Tirana

Email: anagj@hotmail.it

Doi:10.5901/mjss.2015.v6n5p195

\begin{abstract}
Over recent years has been noticed an increase of criminality among juveniles. Taking into consideration the great social sensitivity, which represents this part of society, we share the opinion, to treat penal policies undertaken toward them by the Albanian state. We do this given the fact that we see it as the most significant instrument wich can prevent and repress a minor to ngage in crime. The question that arises us during this paper and that we intend to give an answer is: How effective are our state penale policies toward the minors?
\end{abstract}

Keywords: penal policy, efficiency, criminality, and the juveniles (minors)

\section{Introduction}

These last 20 years, the juvenile criminality as a criminal phenomenon has become a worrisome problem for all Albanian society but not only. Given the high prevalence of this phenomenon and the variety of offenses committed by juveniles, we will treat criminal policies undertaken to combat and prevent this sweeping phenomenon. It must be said that in recent years the criminal justice system has undergone major legislative, institutional changes and above all in the practices followed in preventing criminal activities. Considering the fact that these policies are the most important tool that can prevent and repression the minors get involved in crime, this paper makes us focus on the criminal policies pursued in Albania for juveniles in conflict with law. The purpose of this paper is to analyze the measures taken by the latter and to identify their efficiency as the main actors in combating this phenomenon. It must be admitted that despite numerous developments and changes to the system of juvenile justice has still much to do, to achieve the desired international levels.

\section{Research Methodology}

Methodology used in this paper is focused on the Albanian legislation, together with the changes made and focused on literature in local and foreign currency.

\section{The Evolution of Criminal Policy After ' 90}

It must be admitted that after the collapse of the communist regime, all branches of justice have been involved in a process of continuous reform process. It must be said that also the period of post-communist transition, as in other countries, even in Albania, is characterized by increased criminality (Elezi \& Hysi, 2006). This increase in criminality is closely related to political economic and cultural developments and changes, etc. Of particular importance in the fight against crime is the process of establishing and democratization of the criminal justice system, the judiciary, prosecution, police and penitentiary ones within the legal and institutional reform, based on the experience of Western democratic states (Hysi \& Elezi, 2006). What we can say is that during these years the whole justice system has undergone numerous institutional legislative changes, but even the penitentiary system is under a developing and changing process. A quite big enough effort was also drafting strategies aimed the more humane and professional possible treatment of the convicted persons in general and juveniles in partikular. Training of capacities and professionals who deal with the administration of juvenile justice has been a continuous process. Generally has been an interest of the state and international actors and various NGOs, which have consistently made efforts to raise awareness and professionalism of the main actors in the justice system for juveniles (UNICEF). The purpose of all these criminal and non-criminal policies has been the realization of professional growth of all actors dealing with juveniles like that of judge, prosecutor, lawyer, 
social worker, employees who work in prisons. But what we ascertain, is that despite numerous economic, political, and institucional developments that our country has undergone and the sustained efforts there is still much to be done for the treatment and protection of minors.

\section{Institutional Framework of the System of Administration of Juvenile Justice in Albania}

\subsection{Police}

Police is one of the leading authorities in combating and preventing crime. Institutional tasks of the police are:

- Protects public order and security

- Protects the exercise of freedoms and rights of the person

- Take measures for the prevention and detection of crime

- Saves properties and important public institutions

- Guarantees the enforcement of laws and regulations, that charge it with duties (Article 3)

The task of the police is to prevent crime and identify problematic persons. A person can be arrested and held by police of a maximum of 48 hours, when there are reasonable grounds to suspect that he has committed an offense. This applies to adults as well as to minors. (Leskoviku, 2010). During the arrest, the latter absolutely must not use force that violates the dignity of the person, such a thing is defined by law. Then must immediately not ify the prosecutor and family. When the minor to be questioned by the police, this should be done in the presence of a psychologist unfortunately in order to eliminate physical and psychological violence against minors. But in the end, is concluded that police violence against juvenile delinquents is not eliminated. This shows that there is more to be done in this sector.

\subsection{Judicial Police}

Legal basis: Law no. 8677, dated 02. 11. 2000 "On the organization and functioning of the Judicial " as amended by Law No. 9241, dated 10.06.2004 and 01.03.2012.

The role of the judicial police is become aware of criminal acts in order to prevent further consequences. In our country there is a special sectors to deal with juveniles. At the judicial police there are no statistics on juveniles presented at this sector, while such an information would be very useful. Training of police with regard the human rights, ethics, criminal law for minors, professional conduct, domestic violence is still an issue that does not meet the standard and is not to the required extent (Unicef). Given that very few people are trained and specialized on juveniles and reforms, often this bring shift of persons and the latter due to the lack of information on legislation has brought the rights of juveniles to be infringed from the very during the start of criminal proceedings. This can cause psychological consequences to juveniles.

\subsubsection{Prosecution}

Legal basis : Law No. 8737, dated 12.2.2001 "On the Organization and Functioning of the Prosecutor of the Republic of Albania"

Prosecutor exercises criminal prosecution and represents the accusation and the charge on behalf of the state in court. The role of the prosecutor is huge in the implementation of criminal policy ( Hysi \& Elezi, 2010) . in recent years the role of prosecution has increased significantly, but lacks specialized structures and prosecutors nationwide and at all levels of the prosecution regarding the particularities of the prosecution of criminal offenses committed by juveniles. Only a part of them has participated in several training sessions organized by the School. (UNICEF). More frequent training of prosecutors in connection with minors would be a momentary solution to the creation of a juvenile justice system

\subsubsection{The lawyer for minors}

Legal basis: Law No. 9209, dated 17.7.2003, "On the profession of lawyer in the Republic of Albania".

Under Article 31 of the Constitution, the right of defense is a constitutional right. Albanian legislation guarantees free legal assistance to all persons who do not have access to a lawyer. Protection of minors is compulsory but in practice it is found that there are difficulties due to the legal ignorance and lack of trained lawyers and specialized on juvenilie issues. Required to be trained advocates for a better protection taking into spotlight the best interest of the child. 


\subsubsection{The judicial sistem}

Legal basis: Law no. 8436 dated 28. 12. 1998 "On the organization of the judiciary in the Republic of Albania" as amended by Law No. 8546 dated 5. 11.1999, amended by Law No. 8658 dated 31. 7.2000 and the Law no. 9111 dated 24. 7.2003 etc.

The judicial power is exercised by the court of first instance, courts of appeal and supreme court. There has been discussed more for the establishment of special courts for juveniles, but so far it has remained in discussion phase and nothing has been done until now. The system of juvenile justice must emphasize the welfare of a minor and the principle of proportionality in determining punitive measure against a minor. (The Beijing Rules 5). Regardless that in the judicial system have been marked improvements in the treatment of judges or the transparency of decisions on juveniles there is still much to be done in relation to ensuring the independence of the judiciary. Regarding the juvenile trial, are not few the cases when there is a lack of seriousness on their part. It happens that the matter be delayed without reason or not to provide psychological assistance to juveniles throughout the process. More attention should be paid to juvenile delinquents, given that they are the most vulnerable social strata..

\subsubsection{The detention and juvenile prisons}

Legal basis: the Criminal Code; Code of Criminal Procedure; Law No. 8328, dated 16. 4. 1998 amended by Law No. 9888, dated. 10. 03.2008 and amended by Law No. 10,087, dated 26. 02.2009 "On the rights and treatment of prisoners and detainees". Institutions of enforcement of judgments to prison, are : high security prison, ordinary prison,, low security prison, special institutions, detention institution. Prisons and detention system in RA is subordinate to the Ministry of Justice pursuant to article 17 of the Law 'On the rights and treatment of prisoners and detainees" juveniles regularly serve their sentence in special institutions only to them, and the inability to separate sections of the institutions according to the criteria of this law article..

Under Article 9 of the same law for juvenile convicts and detainees, the preparation for re-integration is realized in cooperation with the minor, social worker, family or his guardian. Juveniles arrested and convicted are treated by respecting the freedoms and rights.

Treatment is based on the best interest of the child, social integration, education and prevention of re-involvement in crime (Article 5). Article 13 of the same law states that minors can be placed in a high security prison and in sections of high-security prison, for behavior and offenses, particularly serious. In practice, all juveniles who committe serious offenses are placed at Vaqarri prison. (UNICEF). There are many plans and discussions for the establishment of detention institutions or special sections in prisons but all have remained just ideas and there is no concrete action toward realization. Detention is the term used for any form of deprivation of liberty, until the final decision by the court on the subject matter. The detention must be authorized by a court. The maximum duration of detention is up to two years, with an extension of of up to three years for specific cases determined depending on the type, risk, and complexity of the crime ( Leskoviku, 2010). Extension of time to stay in custody has become a serious problem. The problems that are evidenced, both in prisons and detention are also numerous. There are no special sections for minors, lacks professional medical assistance with juvenilies. In prisons also lack specialized persons for the care of minors.

\section{Criminal Policies Implemented to Prevent Juvenile Delinquency}

According to numerous statistics, the juvenile criminality has risen and turning into a worrisome problem for the Albanian society but not only. Crimes committed by juveniles have turned in disturbing facts on a society that aims progress, emancipation, development, as anywhere in the world, are becoming more and moreworrying even in Albania. The more incrimination be among minors among the more obscure becomes the perspective of human society (Papandile \& Mandro,2002) . It has been concluded that the most numerous crimes committed by the latter occur in urban areas. Numerous statistics issued by police and the courts, and those of received by studies that has been conducted, show that a large number of juveniles involved in criminal activity come from degraded, uneducated and poor families. Crimes against property or theft are considered to frequent crimes committed by juveniles and young adults (UNICEF). However, minors have committed even criminal offenses such as; murder, injury, drugs, and sexual crimes, political etc. Under Article 12 of the Penal Code of the Republic of Albania, criminal responsibility is attributed to the person that at the time of committing a crime has reached the age of fourteen. A person who commits a criminal offense is kept responsible at the age of sixteen. The law provides educational measures but thoshe have not found implementation.

There are many factors that lead juveniles to delinquent behavior but most of them are personal, family, social 
factors. Practice has shown that abuses or mistreatment and often even the sexual violence that in recent years have become disturbing, leads the latter to engage in criminal behavior. Of a particular importance in the fight against juvenile crime is detection and identification of the latter by the police. After the discovery of juvenile offenders to criminal behavior, in order the fight against this crime to achieve the desired effects, it is essential that they be pursuited and arrested ( Hajdari, 2004). We believe that with the pursuit and arrest of minors involved in criminal activity would be achieved good preventive results. In addition to laws and punitive sanctions, there are the measures taken by noncriminal policies in combating juvenile delinquency, such as those social, cultural, etc. Director of CRCA has made a special contribution in the fight for the protection of children, dealing with individual cases and providing also legal assistance along with that social.

Important administrative reforms have impacted positively on the treatment of minors. An significant reform was the creation of special sanctions for juveniles, in court. The creation of these special sanctions was a requirement of the Code of Criminal Procedure. By decree of the President of the Republic in 2007, was authorized creation of these sanctions in six court districts, based on the current location of the appellate courts ( Leskoviku, 2010). For the treatment of these cases have been appointed specialist judges and this has resulted in an improvement in juvenile justice.. Against the juvenile perpetrators of a criminal offense can not be given more than half of the sentence compared to an adult. Commitment and efforts has had even by the prosecution in the fight against crime, an effort that is to be evaluate. Even in the law on state police there have been improvement in terms of rights of juveniles in conflict with law. Police reform led to the creation of a specialized police unit for the treatment of juveniles involved in crimes and domestic violence. In article 52 of the penal code is anticipated that the minor convicted of a criminal offense should be entered into educational institutions and not in jail but currently they do not exist. So as mentioned above, in the effort to combat and prevent we have a series of measures undertaken and these to some extent have been effective but thi sis not enough. There is a lot more to be done, if we intend international results. Initially, and what is considered as an imperative, it is the creation of a special code, establishment of punitive juvenile institutions where the latter to sufler their punishment separated from adults. But it is of a great importance even role of non-criminal policies as actors involved in the fight against this phenomenon. A collaboration of criminal and non-criminal policies would bring satisfactory results.

\section{Conclusions}

- After 90' the juvenile delinquency has become a matter of high concern for the Albanian society with a significant increase from year to year.

- There is not a special code to minors. The provisions on juvenilies we find scattered through laws and codes and in many cases the minors are treated like adults.

- With regard to how the Albanian legislation applies, it is found to be more punitive

- Undue delay are observed in the investigation and trial of juveniles involved in criminal activity..

- There was an evident improvement in the legislation to protect the rights of minors, but there is still much to be done to achieve international standards.

- Threre is a lack of transparency about the statistics of minors involved in criminal acts by state structures

- Specialized persons dealing with the investigation and the trial of juveniles lack also.

\section{Recommendations}

- There is a must need for the drafting of a special code for minors

- Must be trained and specialized actors of justice system for juvenilies, involved in fighting and preventing juvenile criminality including here, the police, prosecutor, lawyers, judges

- Psychologists and social workers specialized in these

- institutions including the prisons must be present.

- Must be set up reintegration centers for minors

- Society should be constantly be informed about this phenomenon.

- Should be opened as more as possible sports and cultural centers, especially in those areas where the risk for delinquent behavior is higher. 


\section{Bibliography}

Bruqi, F., (2004), "Juvenille deliquence and physical exercices", Pristina

Familly code

Elezi, I., (2006), " Criminology" Pristina

Hajdari, A., (2004), " The juvenile criminality in Kosovo, during the period (2001-2003) Pristina, . fq210, .

Halil, R., (2002), "Criminology" Pristina

Hysi, V., \& Elezi, I., (2006)," Criminal Policy", Pegi, Tirane

The Criminal Code of the Republic of Albania

Constitution of Albania (28/11/1998)

Leskoviku, M., (2010), "The penitentiary system in Albania", Tirana ,design, . p. . 41, 43

Papandie, J.,\& Mandro, I., (2002), " Criminology - Penology " Publishing house llar, . p. 85, .

General Prison Regulation Law 8328 16. 4. 1998 amended by Law 10,087, dated 26.02.2009 Articles, 5, 9, 13, 17

UNICEF "Juvenile justice in Albania", Tirana, p . 27, . 30, . 32

UNICEF (2007), " Delinquency of minors" Tirana. p. 8

Saliu, I., (2005), " "The criminal law for minors " Pristina 